\title{
Criptógamos do Parque Estadual das Fontes do Ipiranga, São Paulo, SP. Algas, 26: Chlorophyceae (famílias Chlorococcaceae e Coccomyxaceae)
}

\author{
Sidney Fernandes ${ }^{1}$ e Carlos Eduardo de Mattos Bicudo ${ }^{1,2}$
}

Recebido: 03.07.2008; aceito: 12.03.2009

\begin{abstract}
Cryptogams of the "Parque Estadual das Fontes do Ipiranga", São Paulo, SP). Algas, 26: Chlorophyceae (families Chlorococcaceae and Coccomyxaceae). Floristic survey of families Chlorococcaceae and Coccomyxaceae (Chlorophyceae) in the Parque Estadual das Fontes do Ipiranga, city of São Paulo, São Paulo State, southeast Brazil. Eleven genera, 30 species and three varieties and one taxonomic forma that are not typical of their respective species and variety were identified. Tetraëdron is the genus with the largest number of species (eight) in the area, and Tetraëdron minimum var. "apiculato-scrobiculatum" the best represented taxon geographically, occurring in four localities. Ankyra judayi, Apodochloris polymorpha, Characium acuminatum, C.ensiforme, C.ornithocephalum var. adolescens, $C$.ornithocephalum var. pringsheimii, C. strictum, C. transvaalense, Chlorococcum acidum, C. minutum, Elakatothrix gelatinosa, Keratococcus mucicola, K. suecicus, Schroederia indica, S. spiralis, Tetraëdron gracile, T. minimum var. minimum, T. planctonicum, $T$. quadrilobatum, T. triangulare, T. trigonum f. trigonum and T. trigonum f. gracile are the least represented ones, occurring in a single locality each.
\end{abstract}

Key words: Brazil, Chlorococcaceae, Coccomyxaceae

RESUMO - (Criptógamos do Parque Estadual das Fontes do Ipiranga, São Paulo, SP. Algas, 26: Chlorophyceae (famílias Chlorococcaceae e Coccomyxaceae). Levantamento florístico das Chlorococcaceae e Coccomyxaceae (Chlorophyceae) do Parque Estadual das Fontes do Ipiranga, Município e Estado de São Paulo, Brasil sudeste. Foram identificados 11 gêneros, 30 espécies e três variedades e uma forma taxonômica que não são as típicas de suas respectivas espécie e variedade. Tetraëdron foi o gênero representado pelo maior número de espécies: oito; e Tetraëdron minimum var. scrobiculatum a espécie que apresentou a maior distribuição geográfica na área do PEFI, ocorrendo em quatro localidades. Ankyra judayi, Apodochloris polymorpha, Characium acuminatum, C. ensiforme, C.ornithocephalum var. adolescens, C.ornithocephalum var. pringsheimii, C. strictum, C. transvaalense, Chlorococcum acidum, C. minutum, Elakatothrix gelatinosa, Keratococcus mucicola, $K$. suecicus, Schroederia indica, S. spiralis, Tetraëdron gracile, T. minimum var. minimum, T. planctonicum, $T$. quadrilobatum, $T$. triangulare, $T$. trigonum f. trigonum e T. trigonum f. gracile apresentaram as distribuições mais restritas, ocorrendo em uma localidade cada uma.

Palavras-chave: Brasil, Chlorococcaceae, Coccomyxaceae

\section{Introdução}

Treze trabalhos constituem o conhecimento das famílias Chlorococcaceae e Coccomyxaceae no PEFI, Parque Estadual das Fontes do Ipiranga, dos quais cinco são de cunho taxonômico e os demais oito de cunho ecológico. Estes últimos apenas relacionam representantes das duas famílias nas listas do material identificado, utilizando os nomes para a interpretação da ecologia da comunidade planctônica ou perifítica.
Moseley (1875) é a primeira menção à ocorrência de representante das famílias em pauta e, em especial, da Chlorococcaceae no Brasil. Baseado em coletas de material subaéreo e epilítico, o referido autor citou a ocorrência de Chlorococcum Meneghini nos Penedos de São Pedro e São Paulo. Quanto ao PEFI, a primeira referência consta em Bicudo \& Bicudo (1967), em um trabalho cuja abordagem é ecológica. Tetraëdron regulare Kützing e $T$. tumidulum (Reinsch) Hansgirg foram aí referidos como constituintes de comunidades flutuantes de

1. Instituto de Botânica, Caixa Postal 3005, 01061-970 São Paulo, SP, Brasil

2. Autor para correspondência: cbicudo@terra.com.br 
algas em um ambiente artificial (hidrofitotério) no Jardim Botânico de São Paulo.

Leite (1974) descreveu e ilustrou 20 gêneros de Chlorococcales incluindo 49 espécies, 12 variedades que não são as típicas de suas respectivas espécies e três formas taxonômicas igualmente não-típicas, no entanto, de suas respectivas variedades dos quais dez espécies [Ourococcus bicaudatus (Hansgirg) Fott, Planktosphaeria gelatinosa G.M. Smith, Polyedriopsis spinulosa (Schmidle) Schmidle, Tetraëdron arthrodesmiformis (G.S. West) Woloszýnska, $T$. gracile (Reinsch) Hansgirg, $T$. minimum (A. Braun) Hansgirg, T. muticum (A. Braun) Hansgirg [hoje Goniochloris mutica (A. Braun) Fott], T. planctonicum G.M. Smith, T. regulare Kützing e T. trigonum (Nägeli) Hansgirg), uma variedade que não é a típica de sua respectiva espécie (Tetraëdron minimum (A. Braun) Hansgirg var. scrobiculatum Lagerheim) e uma forma igualmente não típica, mas de sua respectiva variedade (Tetraëdron trigonum (Nägeli) Hansgirg f. gracile (Reinsch) De Toni] são representantes das famílias Chlorococcaceae e Coccomyxaceae para a área do PEFI. Sant'Anna (1984) inventariou, floristicamente, as Chlorococcales do Estado de São Paulo, incluindo 66 gêneros, 178 espécies, 24 variedades que não são as típicas de suas respectivas espécies e cinco formas também não típicas, porém, de suas respectivas variedades. Desses, cinco gêneros, 11 espécies [Chlorococcum infusionum (Schrank) Meneghini, Ourococcus bicaudatus (Hansgirg) Fott, Polyedriopsis spinulosa (Schmidle) Schmidle, Schroederia indica Philipose, Tetraëdron incus (Teiling) G.M. Smith [hoje Chlorotetraëdron incus (Teiling) Komárek \& Kováčik], T. minimum (A. Braun) Hansgirg e T. quadrilobatum G.M. Smith] e uma variedade não típica [Tetraëdron minimum (A. Braun) Hansgirg var. scrobiculatum Lagerheim] foram documentados para a área do PEFI. Chlorococcum infusionum (Schrank) Meneghini, Keratococcus bicaudatus (A. Braun) Boye-Petersen, K. suecicus Hindák, Polyedriopsis spinulosa (Schmidle) Schmidle, Schroederia indica Philipose, Tetraëdron incus (Teiling) G.M. Smith [hoje Chlorotetraëdron incus (Teiling) Komárek \& Kováčik], T. minimum (A. Braun) Hansgirg var. minimum, T. minimum (A. Braun) Hansgirg var. scrobiculatum Lagerheim e $T$. quadrilobatum G.M. Smith foram identificados por Sant'Anna et al. (1989) para o Lago das Garças. As referidas autoras incluíram breves descrições, medidas e ilustrações dos materiais identificados. Ferragut et al. (2005) referiram a presença de Characium acuminatum A. Braun, C. rostratum Reinhardt, Elakatothrix gelatinosa Wille, Tetraëdron caudatum (Corda) Hansgirg e T. minimum (A. Braun) Hansgirg no Lago do IAG. Tucci et al. (2006) identificaram, ao estudar o Lago das Garças, a ocorrência das seguintes espécies: Chlorococcum infusionum (Schrank) Meneghini, Keratococcus bicaudatus (Hansgirg) Fott, K. suecicus Hindák, Polyedriopsis spinulosa (Schmidle) Schmidle, Schroederia indica Philipose, Tetraëdron caudatum (Corda) Hansgirg, T. incus (Teiling) G.M. Smith [hoje Chlorotetraëdron incus (Teiling) Komárek \& Kováčik], T. minimum (A. Braun) Hansgirg var. minimum, T. minimum (A. Braun) Hansgirg var. scrobiculatum Lagerheim, $T$. quadrilobatum G.M. Smith, T. regulare Kützing e $T$. triangulare Koršikov.

Leite (1974) é o trabalho de maior abrangência taxonômica publicado sobre material do PEFI, porém, muito mais coletas foram feitas desde então na área do Parque. Além disso, uma quantidade significativa de modificações nomenclaturais ocorreu durante os 34 anos que decorreram desde a publicação do trabalho de Leite (1974). Por estas duas razões, decidiu-se providenciar o atual levantamento.

\section{Material e métodos}

Os métodos para coleta, preservação e estudo do material utilizados neste trabalho constam em Bicudo e Menezes (2006). Todas as amostras, seja de perifíton seja de fitoplâncton, encontram-se depositadas no Herbário Científico do Estado "Maria Eneyda P. Kauffmann Fidalgo" (SP) do Instituto de Botânica da Secretaria do Meio Ambiente do Estado de São Paulo.

Visando a mais pronta localização, gêneros, espécies e variedades taxonômicas foram atualmente relacionados em ordem alfabética crescente, sendo as formas dentro de suas respectivas variedades, estas dentro de suas espécies e as últimas dentro dos gêneros competentes. Espécies, variedades e formas taxonômicas que constam da literatura, mas que não foram reencontradas durante o presente levantamento tiveram seus nomes citados nas chaves de identificação e no texto precedidos por um asterisco. O sistema de classificação adotado foi o de Bourrelly (1966), por ser o único que inclui todos os gêneros até então conhecidos, os quais foram classificados segundo critérios uniformemente aplicados a todo o universo dos gêneros nele contidos. 


\section{Resultados e Discussão}

Os 11 gêneros presentemente identificados para o PEFI têm a seguinte situação sistemática:

Divisão Chlorophyta

Classe Chlorophyceae

Ordem Chlorococcales

Família Chlorococcaceae

Ankyra

Apodochloris

Characium

Chlorococcum

Planktosphaeria

Polyedriopsis

Schroederia

Tetraëdron

Família Coccomyxaceae

Elakatothrix

Keratococcus

Planktococcomyxa

\section{CHLOROCOCCACEAE}

Indivíduos unicelulares livres ou fixos a algum substrato, solitários ou coloniais (colônia sem forma definida), às vezes reunidas em agrupamentos irregulares. As células podem ser aproximadamente esféricas e uninucleadas ou, mais raro, com vários núcleos na fase adulta. O cloroplastídio varia em número (ausente até vários), forma (esponjoso, poculiforme, urceolado, estrelado, reticulado, placóide, discóide ou poligonal) e posição (axial ou parietal) e pode ou não possuir um pirenóide. Ocorrem um ou dois vacúolos pulsáteis na base dos flagelos das células vegetativas jovens e dos zoósporos, porém, tais estruturas estão ausentes nas células adultas. A parede celular pode ser lisa ou ornamentada com verrugas, setas ou espinhos. Jamais foi identificada reprodução vegetativa por divisão celular nos representantes desta família (Bourrelly 1966).

\section{Ankyra Fott}

Indivíduos unicelulares isolados. A célula é fusiforme ou mais ou menos cilíndrica, com um espinho em cada pólo e sempre bipolar. O espinho do pólo anterior é normal e o do pólo posterior tem a extremidade bífida ou alargada, de modo a semelhar uma espátula. A parede celular é constituída de duas metades que se encaixam na parte média da célula. Existe apenas um cloroplastídio em forma de banda parietal irregular, com um pirenóide situado no terço mediano da célula.

Uma única espécie foi identificada.

* Ankyra judayi (G.M. Smith) Fott, Preslia 29: 303. 1957.

Figura 1

Indivíduos isolados; célula fusifome, reta ou curva, ápices atenuados, um deles pontiagudo, o outro 2-furcado, 34-70 $\mu \mathrm{m}$ compr. incluindo espinhos, 6,5-7,2 $\mu \mathrm{m}$ larg.; parede celular delicada, firme; cloroplastídio 1, parietal; pirenóide 1 .

Hábitat: plâncton no hidrofitotério (Bicudo \& Bicudo 1970).

A única referência à ocorrência do gênero no Brasil consta em Bicudo \& Bicudo (1970), uma chave para identificação dos gêneros então conhecidos para o Brasil, onde A. ancora (G.M. Smith) Fott f. spinosa (Koršikov) Fott aparece identificada a partir de material coletado no hidrofitotério do Jardim Botânico de São Paulo. A diferença entre a última espécie e $A$. judayi G.M. Smith reside no tipo de plastídio, que na última é laminar e na primeira em forma de " $\mathrm{H}$ ", com o pirenóide localizado na travessa do " $\mathrm{H}$ ".

Discute-se, presentemente, a identificação do material em Bicudo \& Bicudo (1970), que parece melhor ser um representante de $A$. judayi, por não possuir estigma, embora as projeções terminais do espinho basal sejam relativamente mais desenvolvidas, como as de A. ancora (G.M. Smith) Fott.

\section{Apodochloris Komárek}

Indivíduos unicelulares isolados, cuja célula é bipolar, podendo ser elipsóide, piriforme, reniforme, cilíndrica ou fusiforme. A parede celular é fina, no entanto, bastante conspícua. Existe apenas um cloroplastídio em forma de banda parietal, inteiriça ou clatrada por célula, com um pirenóide situado no terço inferior da célula e, em geral, um pouco deslocado para um dos lados.

Do ponto de vista prático, Apodochloris é um Characium que não possui estipe ou mucilagem para fixação ao substrato. Os representantes de Apochloris foram encontrados, até o momento, vivendo no interior da mucilagem colonial de Mycrocystis e Aphanizomenon.

Uma única espécie foi identificada.

Apodochloris polymorpha (Bischoff \& Bold) Komárek, Algological Studies 24: 241. 1979 ”Chlorococcum polymorphum Bischoff \& 
Bold, Phycological studies IV. Some soil algae from Enchanted Rock and related algal species. University of Texas Publication 6318: 1-95. 1963. Figuras 2-3

Célula oblonga a ovalada, 37,6-43,5 $\mu$ m compr., 15,9-17,8 um larg.; cloroplastídio 1, parietal, clatrado; pirenóide 1 , grande, no terço mediano ou posterior (pólo amplamente arredondado) da célula; parede celular fina.

Hábitat: plâncton (SP115417) e perifíton(SP115377) no Lago das Ninféias.

Apodochloris polymorpha (Bischoff \& Bold) Komárek lembra bastante um exemplar de Characium, porém, destituído de pedicelo ou mucilagem de fixação. Para o Brasil, foi identificado somente Apodochloris simplissima (Koršikov) Komárek em Nogueira (1991) e Sophia et al. (2004).

\section{Characium A. Braun}

Indivíduos unicelulares, em geral isolados, que raramente formam pequenos grupos, porém, sempre fixos a algum substrato. A célula pode ser fusiforme, clavada ou subsférica e reta, curva ou torcida em "S". Na maioria das espécies existe um estilete que pode ser mais longo ou mais curto que fixa o indivíduo ao substrato e pode terminar em um disco diminuto. Em algumas poucas espécies, entretanto, na ausência de estilete, a fixação se dá através de uma substância adesiva cimentante. A parede celular é fina, mas, bastante conspícua. Nos indivíduos jovens, o cloroplastídio é único, laminar, parietal e possui um pirenóide central. Em alguns exemplares, entretanto, o plastídio pode fragmentar em vários, cada porção com seu pirenóide.

Chave para as espécies e variedade de Characium.

1. Célula bilateralmente simétrica.
2. Ápice celular mucronado
* C. acuminatum
2. Ápice celular agudo
* C. rostratum

1. Célula bilateralmente assimétrica.

3. Ápice celular prolongado em espinho relativamente longo

C. transvaalense

3. Ápice celular não prolongado em espinho.

4. Pedículo longo, 1/3-1/2 do comprimento total da célula ... C. ornithocephalum var. ornithocephalum

4. Pedículo curto, ca. 1/10 do comprimento total da célula.

5. Célula fusiforme ou subfusiforme.

6. Célula 15-18,8 $\mu \mathrm{m}$ compr., 4-5 $\mu \mathrm{m}$ larg * C. ornithocephalum var. pringsheimii

6. Célula 29-32 $\mu \mathrm{m}$ compr., 6-6,5 $\mu \mathrm{m}$ larg. C. ensiforme

5. Célula lanceolada ou subclavada.

7. Célula moderadamente lanceolada, ápice acuminado...* C. ornithocephalum var. adolescens

7. Célula subclavada, ápice arredondado C. strictum

* Characium acuminatum A. Braun in Kützing, Species Algarum. 892. 1849.

Figura 4

Indivíduos curto-pediculados, mais ou menos perpendiculares ao substrato, pedículo ca. 1/5 do comprimento total da célula; célula amplamente elíptico-fusiforme, levemente assimétrica, margens laterais desigualmente convexas, ápice mucronado, disco de fixação ausente, 7-13 $\mu \mathrm{m}$ compr., ca. 7,5 um larg.; cloroplastídio 1, laminar, parietal, ocupando quase toda a periferia celular; pirenóide 1 , supramediano; parede celular delicada.
Hábitat: perifíton no Lago do IAG (SP390876). Characium acuminatum A. Braun lembra $C$. ornithocephalum A. Braun var. adolescens Printz, mas difere por não apresentar o ápice celular projetado em um rostro acuminado e apresentar uma incrustação na base de fixação. Exemplares da espécie foram coletados sempre epífitos por um curto pedículo em algas cocóides.

Characium ensiforme Hermann, Über die bei Neudamm aufgefundenen Arten der Genus Characium. 26: pl.6B, fig. 1. 1863.

Figura 5 
Indivíduos curto-pediculados, mais ou menos perpendiculares ao substrato, pedículo ca. 1/10 do comprimento total da célula, almofadado; célula fusiforme assimétrica, margens assimétricas, uma delas pouco convexa, a outra mais acentuadamente convexa, ápice agudo, extremidade arredondada,

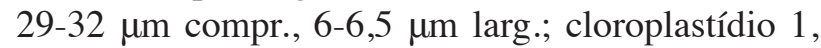
laminar, parietal, revestindo quase toda a célula; pirenóide 1, central; parede celular delicada.

Hábitat: perifíton no Lago das Ninféias (SP390876).

Com base apenas na morfologia, é impossível diferir a presente espécie de $C$. indicum Patel \& I. George e C. hindakii Lee \& Bold. A diferença reside, em parte, nas medidas, mas, principalmente, na relação entre o comprimento e a largura da célula (Tabela 1).

Characium ornithocephalum A. Braun var. ornithocephalum, Algarum unicellularum genera nova vel minus cognita. 42: pl. 3, fig. C1-11. 1855.

Figura 6

Indivíduos médio a longo-pediculados, perpendiculares a inclinados sobre o substrato, pedículo longo, ca. 1/3-1/2 do comprimento total da célula, almofadado; célula falciforme, moderadamente assimétrica, margens mais ou menos uniformemente convexas, ápice acuminado, extremidade pontiaguda, ca. 15,1 $\mu$ m compr., ca. 3,9 $\mu \mathrm{m}$ larg.; cloroplastídio 1, laminar, parietal, revestindo ao redor de $1 / 2$ da célula; pirenóide 1, central; parede celular delicada.

Hábitat: perifíton no Lago das Garças (SP390877) e no Lago das Ninféias (SP390876).

* Characium ornithocephalum A. Braun var.adolescens

Printz, Skrifter udg. af Videnskabsselskabet i

Christiania 1913(6): 39, pl. 2, fig. 40-51. 1914.

Figuras 7-8
Indivíduos curto-pediculados, perpendiculares a pouco inclinados sobre o substrato, pedículo curto, ca. 1/10 do comprimento total da célula; célula moderadamente lanceolada, levemente assimétrica, margens não uniformemente convexas, ápice acuminado, 21-24,5 $\mu \mathrm{m}$ compr., 7-8 $\mu \mathrm{m}$ larg.; cloroplastídio 1, laminar, parietal, revestindo ao redor de 9/10 da célula; pirenóide 1, central; parede celular delicada.

Hábitat: perifíton no Lago das Ninféias (SP390876).

Os representantes desta variedade diferem dos da típica da espécie pelo menor grau de assimetria da célula, pelo pedículo bastante mais curto e pela menor inclinação de seus indivíduos sobre o substrato (Komárek \& Fott 1983).

* Characium ornithocephalum A. Braun var. pringsheimii (A. Braun) Komárek, Algological Studies 24: 243. 1979 三 Characium pringsheimii A. Braun, Algarum unicellularum genera nova vel minus cognita, 106. 1855.

Figuras 9-11

Indivíduos curto-pediculados, perpendiculares a pouco inclinados sobre o substrato, pedículo curto, ca. 1/10 do comprimento total da célula; célula subfusiforme, levemente assimétrica, margens não igualmemente convexas, ápice apiculado, 15-18,8 $\mu \mathrm{m}$ compr., 4-5 $\mu \mathrm{m}$ larg.; cloroplastídio 1, laminar, parietal, revestindo ao redor de 9/10 da célula; pirenóide 1, central; parede celular delicada.

Hábitat: perifíton no Lago das Ninféias (SP390876).

Esta variedade difere da típica da espécie pelo menor comprimento do pedículo e pela maior assimetria da célula (Komárek \& Fott 1983).

Tabela 1. Comparação das medidas do comprimento e da largura celular e da relação entre o comprimento e largura celular de Characium ensiforme, C. indicum e C. hindakii.

Table 1. Comparison of cell length and breadth measurements and the cell length-breadth ratio of Characium ensiforme, C. indicum and C. hindakii.

\begin{tabular}{lccc}
\hline Espécie & Comprimento celular & Largura celular & Relação C : L \\
\hline Characium ensiforme & $29-32 \mu \mathrm{m}$ & $6-6,5 \mu \mathrm{m}$ & $4,8-4,9$ \\
Characium indicum & $27,6-34,7 \mu \mathrm{m}$ & $3,5-4,7 \mu \mathrm{m}$ & $7,4-7,9$ \\
Characium hindakii & $85 \mu \mathrm{m}$ & $23 \mu \mathrm{m}$ & 3,6 \\
\hline
\end{tabular}


* Characium rostratum Reinhardt, Skrifter udg. af Videnskabsselskabet i Christiania 1913(6): 41. 1914.

\section{Figura 12}

Indivíduos curto-pedicelados, mais ou menos perpendiculares ao substrado, pedículo ca. 1/13 do comprimento total da célula; célula subfusiforme, margens mais ou menos uniformemente convexas, ápice agudo, extremidade arredondada, 17-35,6 um compr., (4,5-)6-13,2 $\mu \mathrm{m}$ larg.; cloroplastídio 1, laminar, parietal, revestindo quase toda a célula; pirenóide 1, central; parede celular delicada.

Hábitat: perifíton no Lago das Garças (SP390877) e no Lago das Ninféias (SP390876).

Poucos exemplares presentemente observados apresentaram disco de fixação. A literatura especializada mostra variação significativa no comprimento do pedículo e na existência de um disco de fixação. Segundo Braun (1855), tamanho do disco de fixação parece depender do estágio de desenvolvimento do material.

Characium rostratum Reinhardt ocorreu sempre epífita e foi encontrado tanto de maneira isolada quanto em grupos sobre o talo de outras algas unicelulares maiores, algas filamentosas e sobre macrófitas aquáticas.

Characium strictum A. Braun, Algarum unicellularum genera nova vel minus cognita: 37, pl. 5A, fig. 1-15. 1855.

\section{Figura 13}

Indivíduos curto-pediculados, perpendiculares ao substrato, pedículo ca. 1/10 do comprimento total da célula; célula subclavada, margens irregulares, um tanto assimétricas, ápice arredondado, ca. 20,5 $\mu \mathrm{m}$ compr., ca. 4,6 $\mu \mathrm{m}$ larg.; cloroplastídio 1, laminar, parietal, revestindo quase toda a célula; pirenóide ausente.

Hábitat: perifíton no Lago das Ninféias (SP390898) e Bicudo (1996: como C. hookeri).
Characium transvaalense Cholnoky, Bericht des Naturwissenschaftlich-medizinischen Vereins in Innsbruck 56: 131. 1954.

Figura 14

Indivíduos curto-pediculados, mais ou menos perpendiculares ao substrato, ca. $22 \mu \mathrm{m}$ compr., ca. 5 um larg., pedículo ca. 1/13 do comprimento total da célula, almofadado; célula fusiforme, levemente assimétrica, margens mais ou menos uniformemente convexas, ápice agudo, terminando em espinho relativamente longo; cloroplastídio 1, laminar, parietal, revestindo quase toda a célula; pirenóide 1 , central; parede celular delicada.

Hábitat: perifíton no Lago das Garças (SP390878).

A literatura ilustra espécimes de C.ornithocephalum A. Braun var. longisetum Ettl sempre fortemente assimétricos, praticamente falciformes. Cholnoky (1954) propôs $C$. transvaalense diagnosticando-o pela célula fusiforme, reta, longo-pediculada e pela posse de um espinho relativamente longo no pólo livre da célula. O referido autor apresentou somente as medidas do comprimento celular: 36-37 $\mu \mathrm{m}$ compr. sem incluir o pedículo (Cholnoky 1954).

Ettl (1968) identificou originalmente $C$. ornithocephalum A. Braun var. longisetum Ettl pela célula assimétrica, muito arqueada e fortemente inclinada sobre o substrato. Os exemplares que Ettl (1968) examinou mediram 18-25 um compr. e 4-5 $\mu \mathrm{m}$ larg. $\mathrm{O}$ atual material do PEFI é extremamente semelhante ao de Ettl (1968), inclusive as medidas. Komárek \& Fott (1983) consideraram C.transvaalense Cholnoky idêntico a $C$. ornithocephalum A. Braun var. longisetum Ettl, uma atitude com a qual não concordamos por se tratar de materiais demasiadamente diferentes um do outro (tabela 2). Conforme a referida tabela 2, C. ornithocephalum A. Braun var. longisetum Ettl tem a célula bilateralmente simétrica, fortemente inclinada em relação ao substrato e comprimento (sem pedículo) sensivelmente menor. Os exemplares ora

Tabela 2. Comparação das características diferenciais entre Characium ornithocephalum var. longisetum e C. transvaalense.

Table 2. Comparison of the differential characteristics of Characium ornithocephalum var. longisetum and C. transvaalense.

\begin{tabular}{lcc}
\hline Característica & C.ornithocephalum var. longisetum & C. transvaalense \\
\hline Simetria celular & assimétrica & simétrica \\
Posição da célula em relação ao substrato & Fortemente inclinada & Vertical ou quase \\
Medidas (sem estipe) & $18-25 \times 4-5 \mu \mathrm{m}$ & $36-37 \times 4-5 \mu \mathrm{m}$ \\
\hline
\end{tabular}


examinados foram identificados com C.transvaalense Cholnoky por que têm a célula bilateralmente simétrica, em geral perpendicular (raro quase) ao substrato e maior comprimento celular.

Todos os espécimes coletados no PEFI foram encontrados epifitando plantas de Oedogonium.

\section{Chlorococcum Meneghini, nomen conservandum}

Indivíduos unicelulares, em geral, isolados, mas podem ser gregários de modo a formar agrupamentos temporários, sem forma definida, que podem ou não ser envolvidos por mucilagem. A célula é esférica ou quase. A parede celularé fina, porém, sempre conspícua. O cloroplastídio é único por célula, ocupa posição parietal e tem a forma de uma taça (ciatiforme), um copo (poculiforme) ou de uma urna (urceolado). Pode existir um ou vários pirenóides por célula.

Chave para as espécies de Chlorococcum

1. Célula oblonga C. acidum

1. Célula esférica ou elipsóide.

2. Célula elipsóide .................... C. ellipsoideum

2. Célula esférica ou quase.

3. Célula 5-10 mm diâm........C. infusionum

3. Célula ca. $16,3 \mathrm{~mm}$ diâm......C. minimum

Chlorococcum acidum Archibald \& Bold, University Texas Publications 7015: 21, fig. 9, 38-39. 1970.

Figuras 15-17

Indivíduos isolados; células oblongas, 8,5-16 um compr.; cloroplastídio 1, parietal, ciatiforme, situado lateralmente; pirenóide 1, com bainha de amido; parede celular relativamente espessa.

Hábitat: perifíton no Lago das Ninféias (SP390876).

Os indivíduos ora identificados apresentaram a célula sempre oblonga, mas a espécie pode incluir formas desde esféricas até elipsóides. Apresentaram também um plastídio apenas por célula, jamais fragmentado em pedaços, o que pode acontecer nas formas mais velhas desta espécie. Finalmente, o maior número dos indivíduos apresentou-se isolado; só raramente formaram grupos de quatro ou cinco.

Chlorococcum ellipsoideum Deason \& Bold, University Texas Publications 6022: 20, fig. 2025, 90-92. 1960.

Figuras 18-19
Indivíduos em geral gregários, formando pequenos grupos de 3-6 células, destituídos de envoltório de mucilagem; células adultas mais ou menos elipsóides, raro subesféricas, 5-8 $\mu \mathrm{m}$ compr., 3,8-4,6 um larg.; cloroplastídio 1, parietal, poculiforme a urceolado, parte basal bem desenvolvida; pirenóide 0-1, quando presente situado basalmente na célula; parede celular espessa.

Hábitat: perifíton no Lago das Garças (SP390906) e no Lago das Ninféias (SP390876, SP390876).

Chlorococcum ellipsoideum Deason \& Bold pode ser confundido com C. pulchrum Archibald \& Bold, mas o último possui os pirenóides situados lateralmente na célula e as dimensões celulares pouco maiores [1017(-20) $\mu \mathrm{m}$ compr., 7,5-13(-15) $\mu \mathrm{m}$ larg.].

Foram encontradas algumas células com a parede celular bastante espessa e o conteúdo protoplasmático bastante denso, um tanto granuloso, que lembram hipnósporos ou algum outro tipo de forma de resistência. Contudo, não foram observadas formas que indicassem sua germinação.

Chlorococcum infusionum (Schrank) Meneghini,

Memorie della Accademia delle scienze di Torino: sér. 2, 5: 27, pl. 2, fig. 3.1842 三 Lepra infusionum Schrank, Annalen der Botanik 9: 4. 1794.

Figuras 20-21

Indivíduos em geral isolados, raro formando pequenos grupos; células adultas esféricas ou quase, raro um tanto elipsóides, 5-12,5 $\mu \mathrm{m}$ diâm.; cloroplastídio 1, parietal, poculiforme a urceolado; parede celular variando desde delicada até espessa.

Hábitat: plâncton no Lago das Garças (Sant'Anna et al. 1989) e no Lago do IAG (SP390867).

Chlorococcum cf. minimum Ettl \& Gärtner, Nova Hedwigia 44: 511. 1987.

Figuras 22-23

Indivíduos isolados; células jovens elipsóides a ovóides, células adultas esféricas ou quase, 16,317,5 $\mu \mathrm{m}$ diâm.; cloroplastídio parietal, mais ou menos acentuadamente urceolado, parte basal bem desenvolvida, bordo liso; pirenóide 1, na parte basal; parede celular espessa.

Hábitat: plâncton no Lago do IAG (SP390880).

Só dois espécimes deste tipo foram encontrados em todo o material examinado, contudo, as feições diagnósticas de ambos (células adultas esféricas de pequeno porte, cloroplastídio urceolado e pirenóide presente, com bainha de amido evidente) foram 
suficientemente inequívocas para permitir sua identificação taxonômica com grande probabilidade de acerto. Os representantes desta espécie podem ser confundidos com os de C. infusionum (Schrank) Meneghini, porém, são distintos em pequenos detalhes como, por exemplo, no tamanho dos indivíduos, na reprodução sexuada que não ocorre em C. infusionum (Schrank) Meneghini e no número de placas de amido que envolve o pirenóide, as quais são poucas (duas a cinco) em $C$. infusionum (Schrank) Meneghini e muitas em C. minimum Ettl \& Gärtner. Quanto ao tamanho, entretanto, as medidas dos menores indivíduos de C. infusionum (Schrank) Meneghini recobrem as dos maiores de C. minimum Ettl \& Gärtner. Reprodução sexuada é dificilmente encontrada na natureza e as placas de amido que circundam o pirenóide são de difícil visualização ao microscópio óptico.

\section{Planktosphaeria G.M. Smith}

Indivíduos unicelulares de vida livre, em geral isolados ou, raramente, reunidos sem qualquer arranjo especial de modo a formar colônias envoltas por uma bainha homogênea de mucilagem. A célula é esférica. O cloroplastídio é único e poculiforme nas células jovens ou vários, mais ou menos poligonais, nas células adultas, porém, sempre parietais na célula. Em qualquer caso, entretanto, o pirenóide é único e aproximadamente central no plastídio.

Uma única espécie foi identificada.

* Planktosphaeria gelatinosa G.M. Smith, Transactions of the Wisconsin Academy of Sciences, Arts and Letters 19(1): 627, pl. 10, fig. 8-11. 1918.

Figura 24

Indivíduos coloniais, colônias 30-80 um diâm.; células esféricas, irregularmente distribuídas no interior de um envoltório de mucilagem abundante, 10-15,4 $\mu \mathrm{m}$ diâm.; cloroplastídios vários, poligonais, parietais; pirenóide 1, central por plastídio; parede celular delicada.

Hábitat: plâncton no Lago das Ninféias, no hidrofitotério e no Lago da Nascente (Leite 1974).

\section{Polyedriopsis Schmidle}

Indivíduos unicelulares de vida livre, usualmente isolados ou, raramente, gregários. A célula tem a forma de uma almofada (todos os ângulos num mesmo plano) ou um tanto piramidal (ângulos em planos distintos), com quatro ou cinco ângulos levemente agudos, retos ou, em geral, obtusos, cada qual ornado com um a dez espinhos (setas) bastante delicados e que afilam gradualmente para o ápice. O cloroplastídio é único por célula, tem forma laminar e ocupa posição lateral na célula. O pirenóide é, em geral, único e situa-se lateralmente na célula.

Uma única espécie foi identificada.

* Polyedriopsis spinulosa (Schmidle) Schmidle, Biologisches Zentralblatt 5(1): 17-18. 1899. Tetraëdron spinulosa Schmidle, Allgemeine botanischen Zeitschrift 2: 193, fig. 2. 1896.

Figuras 25-27

Indivíduos solitários; célula piramidal, margens côncavas ou levemente convexas, ângulos truncados, 2-4 setas por ângulo, 20-24 $\mu \mathrm{m}$ de um ângulo ao outro, setas (13-)25-35 um compr.; cloroplastídio 1, laminar, parietal; pirenóide 1, lateral na célula; parede celular delicada.

Hábitat: plâncton no lago artificial no 12 (SP130973), Leite (1974), Sant'Anna (1984) e no Lago das Garças (Sant'Anna et al. 1989, Tucci et al. 2006).

Polyedriopsis spinulosa (Schmidle) Schmidle é, aparentemente, a única espécie do gênero e é facilmente reconhecida pela forma de almofada de suas células, cujos ângulos são ornados com tufos de espinhos.

\section{Schroederia Lemmermann}

Indivíduos unicelulares, solitários, de vida livre. A célula é alongada, fusiforme e pode ser reta, levemente curva ou torcida em forma de "S", porém, com as extremidades sempre continuando em um espinho sólido, relativamente longo e pontiagudo. A célula jovem tem apenas um cloroplastídio laminar, de situação parietal e lateral, com um pirenóide localizado mais ou menos na porção central do plastídio. Quando adulta, tem vários plastídios parietais, laterais, com a forma de bandas transversais, cada qual com um pirenóide.

Chave para as espécies de Schroederia.

1. Setas longas, retas ou muito levemente curvas S. antillarum

1. Setas relativamente curtas, retas ou regular ou irregularmente curvas, até torcidas em espiral.

2. Setas regular ou irregularmente curvas, até torcidas em espiral S. spiralis

2. Setas retas, raro muito pouco curvas S. indica 

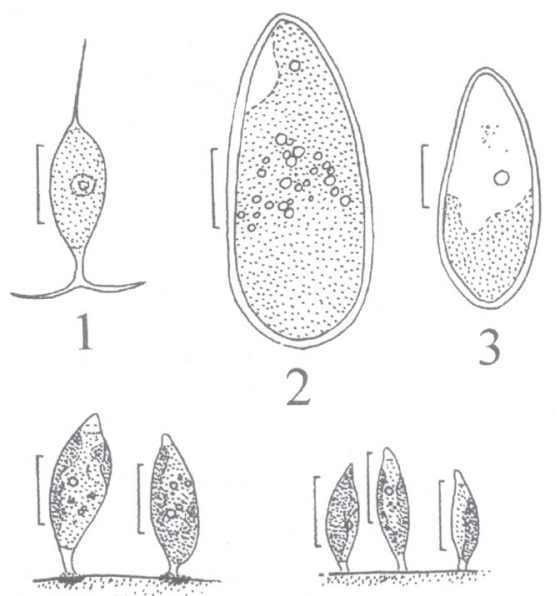

78

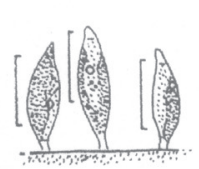

91011

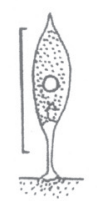

4

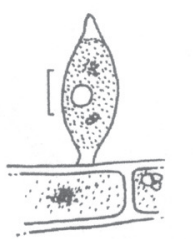

12
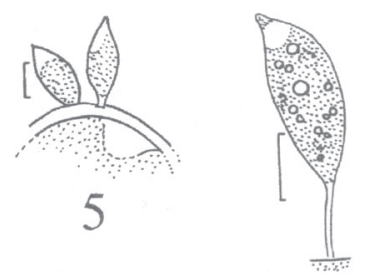

6
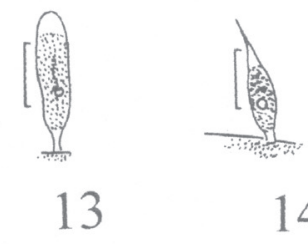

13

14

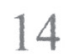

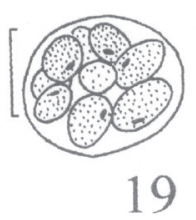
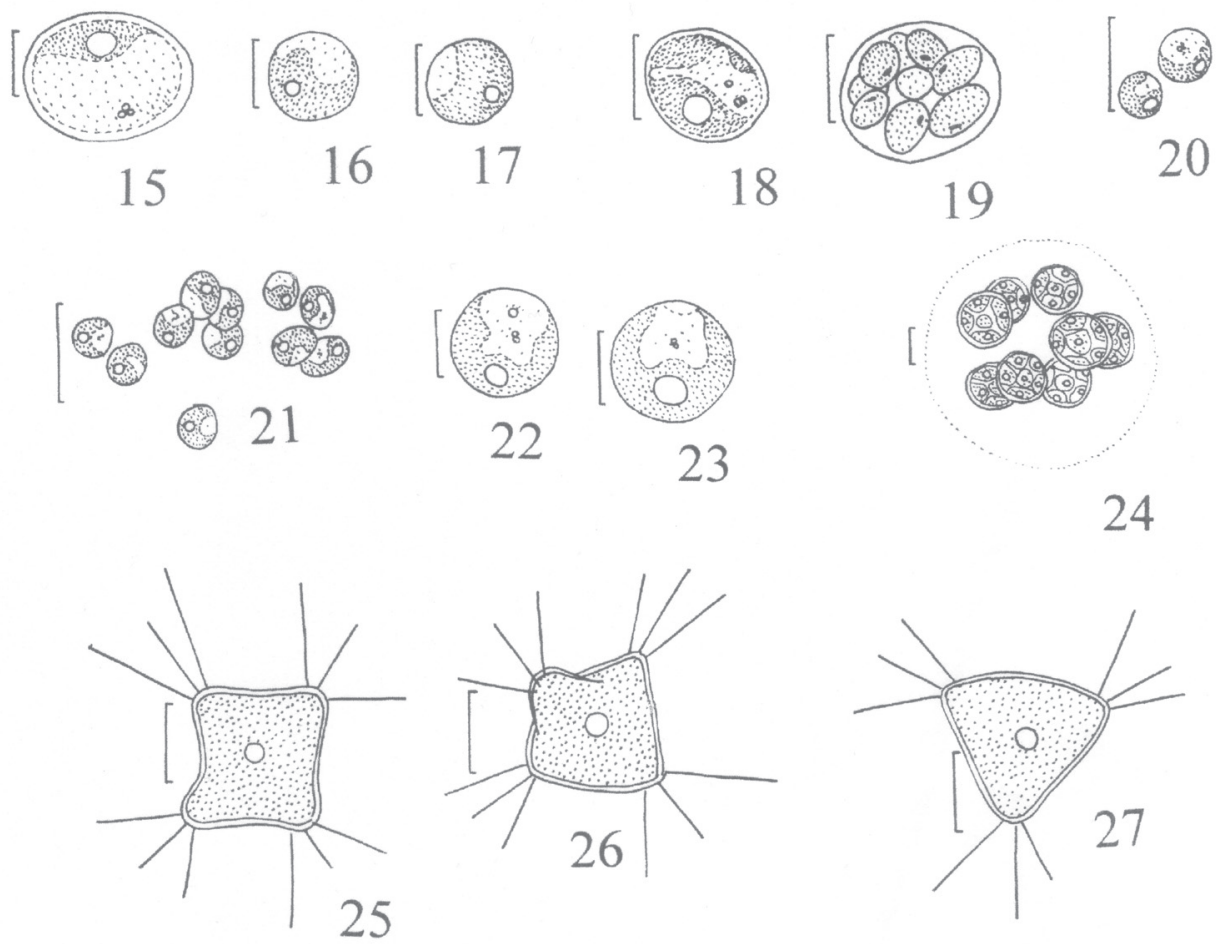

24

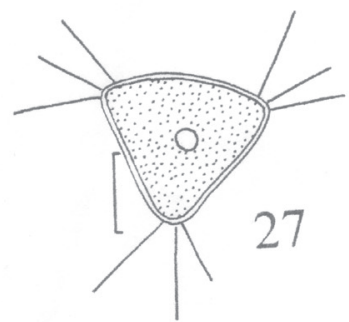

Figuras 1-27. Espécies de Chlorococcaceae do Parque Estadual das Fontes do Ipiranga. 1. Ankyra judayi (modificado de Bicudo \& Bicudo 1970). 2-3. Apodochloris polymorpha. 4. Characium acuminatum. 5. Characium ensiforme. 6. Characium ornithocephalum var. ornitocephalum (de Bicudo 1996). 7-8. Characium ornithocephalum var. adolescens (de Bicudo 1996). 9-11. Characium ornithocephalum var. pringsheimii (de Bicudo 1996). 12. Characium rostratum. Figura 13. Characium strictum. (de Bicudo 1996). 14. Characium transvaalense. 15-17. Chlorococcum acidum, 15. Esporo (?).18-19. Chlorococcum ellipsoideum, 19. Zoósporos no interior da parede da célula-mãe. 20-21. Chlorococcum infusionum. 22-23. Chlorococcum minimum. 24. Planktosphaeria gelatinosa (de Sant'Anna 1984). 25-27. Polyedriopsis spinulosa (de Sant'Anna 1984).

Figures 1-27. Species of Chlorococcaceae of the "Parque Estadual das Fontes do Ipiranga". 1. Ankyra judayi (modified from Bicudo \& Bicudo 1970). 2-3. Apodochloris polymorpha. 4. Characium acuminatum. 5. Characium ensiforme. 6. Characium ornithocephalum var. ornitocephalum (from Bicudo 1996). 7-8. Characium ornithocephalum var. adolescens (from Bicudo 1996). 9-11. Characium ornithocephalum var. pringsheimii (from Bicudo 1996). 12. Characium rostratum. 13. Characium strictum (from Bicudo 1996). 14. Characium transvaalense. 15-17. Chlorococcum acidum. 15. Spore (?).18-19. Chlorococcum ellipsoideum. 19. Zoospores inside the mother cell wall. 20-21. Chlorococcum infusionum. 22-23. Chlorococcum minimum. 24. Planktosphaeria gelatinosa (from Sant'Anna 1984). 25-27. Polyedriopsis spinulosa (from Sant'Anna 1984). 
Schroederia antillarum Komárek, Nova Hedwigia 37: 74, pl. 2, fig. 2. 1983.

Figura 28

Indivíduos isolados; células fusiformes, 53,9$65 \mu \mathrm{m}$ compr. incluindo espinhos, ca. $2 \mu \mathrm{m}$ larg., setas longas, retas ou muito levemente curvas, 5-5,5 vezes mais longas que o corpo da célula, ca. $20 \mu \mathrm{m}$ compr.; parede celular delicada, firme; cloroplastídio 1, parietal, laminar, ocupando toda periferia celular, bordo liso; pirenóide 1.

Hábitat: plâncton no lago artificial no 6 (SP115427); perifiton no Lago das Garças (SP390826, SP390903).

Schroederia indica Philipose, Chlorococcales: 90, fig. 19. 1967.

Figura 29

Indivíduos isolados; células em geral lunadas, às vezes fusiformes, (31,5-)54-60 $\mu \mathrm{m}$ compr. incluindo espinhos, ca. $34 \mu \mathrm{m}$ sem espinhos, 3-6 $\mu \mathrm{m}$ larg., 1018 vezes mais longas que largas (incluindo espinhos), setas relativamente curtas, retas, raro muito pouco curvas, 0,7-0,8 vezes mais longas que o corpo da célula, 8,1-9,4 $\mu \mathrm{m}$ compr.; parede celular delicada, firme; cloroplastídio 1, parietal, laminar, ocupando toda periferia celular, bordo liso; pirenóides 1-4.

Hábitat: plâncton no Lago das Garças (SP390899), Sant'Anna et al. (1989) e Tucci et al. (2006).

Schroederia spiralis (Printz) Koršikov, Chlorococcales. 90, fig. 19. 1967 = Ankistrodesmus nitzschioides
(G.S. West) var. spiralis Printz, Nova Acta Regiae Societatis Scientiarum Upsaliensis: sér. 4, 14(5): 60, pl. 10, fig. 1-11. 1949.

Figuras 30-31

Indivíduos isolados; células fusiformes, 12-30 $\mu \mathrm{m}$ compr. incluindo espinhos, 5-8 $\mu \mathrm{m}$ larg., setas relativamente curtas, regular ou irregularmente curvas e até torcidas em hélice (saca-rolhas), raro retas, 1-1,5 vezes mais longas que o corpo da célula, 9,6-12,8 $\mu \mathrm{m}$ compr.; parede celular delicada, firme; cloroplastídio 1, parietal, laminar, ocupando toda periferia celular, bordo liso; pirenóide 1.

Hábitat: perifíton no Lago das Garças (SP390904).

\section{Tetraëdron Kützing}

Indivíduos unicelulares de hábito solitário e vida livre. A forma da célula é extremamente variada, podendo ser triangular, quadrangular, tetraédrica e até poliédrica. Dessas formas, a tetraédrica é a mais comum. Os ângulos podem se apresentar projetados em processos simples ou ramificados ou terminar em espinhos curtos e grosseiros ou delicados, no entanto, sempre mais longos que o corpo da célula, cuja base é inflada em algumas espécies. A parede celular varia entre lisa e decorada com escrobículos ou verrugas, porém, essa decoração não apresenta qualquer organização especial. O cloroplastídio é único por célula, sua forma acompanha a forma da célula e a localização é parietal. O pirenóide também é único por célula e situa-se aproximadamente no centro da célula.

Chave para as espécies, variedades e formas taxonômicas de Tetraëdron

1. Cloroplastídio com pirenóide.

2. Célula 3-angular.

3. Célula $8,5-10,5 \mu \mathrm{m}$ de um ângulo ao outro oposto * T. triangulare

3. Célula ca $20 \mu \mathrm{m}$ de um ângulo ao outro oposto.

4. Ângulos pouco pronunciados que alcançam, no máximo, $1 / 4$ do corpo celular * T. trigonum var. trigonum

4. Ângulos bastante pronunciados que alcançam, no mínimo, 1/3 do corpo celular * T. trigonum f. gracile

2. Célula 4-5-angular.

5. Célula 4-angular.

6. Ângulos arredondados ou acuminados, destituídos de espinho ou processo.

7. Ângulos acuminados * T. quadrilobulatum (em parte)

7. Ângulos arredondados.

8. Ângulos acutangular-arredondados *T. quadrilobulatum (em parte)

8. Ângulos retangular-arredondados. 
9. Parede celular lisa * T. minimum var. minimum

9. Parede celular pontuada * T. minimum var. scrobiculatum

6. Ângulos com espinho ou extremidade 2-denticulada ou 2-lobulada.

10. Ângulos prolongados em processo curto, extremidade 2-denticulada

* T. planctonicum (em parte)

10. Ângulos 2-lobados, lobos relativamente longos, extremidade 2-denticulada * T. gracile

5. Célula 5-angular.

11. Célula com 4 lados retos a suavemente côncavos e o outro com uma incisão profunda

T. caudatum

11. Célula com os 5 lados convexos * T. planctonicum (em parte)

1. Cloroplastídio sem pirenóide.

12. Ângulos acuminados terminados em espinho bastante curto * T. regulare

12. Ângulos destituídos de espinho ou processo * T.quadrilobulatum (em parte)

Tetraëdron caudatum (Corda) Hansgirg, Hedwigia 27: 131.1888 = Astericium caudatum Corda, Almanach de Carlsbad 9: 238, pl. 1, fig. 2. 1839.

Figuras 32-33

Células isoladas, achatadas, 5-angulares, 4 lados retos a suavemente côncavos, o outro com 1 incisão profunda, ângulos arredondados, todos terminados em 1 espinho, (5-)7,2-12,6 $\mu \mathrm{m}$ de um ângulo ao outro oposto; cloroplastídio 1, parietal; pirenóide 1, central ou não.

Hábitat: plâncton e perifíton no Lago do IAG (SP390905) e Ferragut et al. (2005); e plâncton no Lago das Garças (Tucci et al. 2006).

Trata-se de uma das espécies do gênero de mais fácil identificação por conta da forma pentagonal da célula em que quatro margens são levemente côncavas ou até retilíneas e uma apresenta uma incisão mais ou menos profunda.

Sant'Anna (1984) afirmou ser esta uma espécie relativamente rara no Estado de São Paulo, desde que foi coletada apenas no Município de Arujá. No PEFI, T. caudatum (Corda) Hansgirg ocorreu no plâncton e no perifíton do Lago do IAG e no plâncton do Lago das Garças, porém, em quantidade relativamente grande.

O exemplar figurado em Tucci et al. (2006) mostrou todos os lados retos ou muito suavemente convexos, sem o lado inciso típico desta espécie.

* Tetraëdron gracile (Reinsch) Hansgirg, Hedwigia 28(1): 191889 三 Polyedrium gracile Reinsch, Notarisia 3(11): 502, pl. 6, fig. 1b-c. 1888.

Figura 34

Células isoladas, achatadas, 4-angulares, margem entre ângulos côncava, ângulos 2-lobados, lobos estreitos, relativamente longos, terminados por 2 dentículos paralelos ou pouco divergentes entre si, ca. $40 \mu \mathrm{m}$ de lado incluindo processos, ca. $16 \mu \mathrm{m}$ sem processos; cloroplastídios vários, parietais, aproximadamente discóides; pirenóide não observado.

Hábitat: plâncton no lago artificial situado próximo da portaria $\mathrm{n}^{\circ} 2$ do Instituto de Botânica (SP115431), Leite (1974) e Sant'Anna (1984).

* Tetraëdron minimum (A. Braun) Hansgirg var. minimum, Hedwigia 27(5-6): 131, pl. 3, fig. 18. 1888 = Polyedrium minimum A. Braun, Algarum unicellularum genera nova vel minus cognita: 94. 1855.

Figuras 35-36

Células isoladas, achatadas, 4-angulares, margem entre os ângulos côncava, ângulos arredondados, destituídos de espinhos ou processos, às vezes com 1 papila, 8-16,5 $\mu \mathrm{m}$ de um ângulo ao outro oposto; cloroplastídio 1, parietal; pirenóide 1, central.

Hábitat: plâncton no Lago das Garças (Sant'Anna et al. 1989).

* Tetraëdron minimum (A. Braun) Hansgirg var. "apiculato-scrobiculatum" (Reinsch, Lagerheim) Skuja, Nova Acta Regiae Societatis Scientiarum Upsaliensis: sér. 4, 16(3): 176, pl. 26, fig. 19. 1956 $\equiv$ (?): Polyedrium minimum A. Braun f. apiculata Reinsch, Notarisia 3(11): 499, pl. 4, fig. 2c. 1888 三 (?): Tetraëdron minimum (A. Braun) Hansgirg var. scrobiculatum Lagerheim, Notarisia 3(12): 591. 1888.

Figura 37

Células isoladas, achatadas, 4-angulares, margem entre ângulos côncava, ângulos arredondados, 
destituídos de espinho ou processo, 6,5-12 $\mu \mathrm{m}$ de um ângulo ao outro oposto; cloroplastídio 1, parietal; pirenóide 1, central.

Hábitat: plâncton no Lago das Garças (Leite 1974, Sant'Anna et al. 1989), no Lago das Ninféias e no lago artificial situado próximo da portaria ${ }^{\circ} 2$ do Instituto de Botânica (Leite 1974, Sant'Anna 1984); perifíton e plâncton no Lago do IAG (Ferragut et al. 2005).

A parede celular pontuada difere a atual var. scrobiculatum Lagerheim da típica da espécie. Autores como Smith (1920), por exemplo, não considera pontuação da parede uma característica suficiente para separar as duas variedades em questão. Para o último autor, a var. scrobiculatum Lagerheim seria um sinônimo heterotípico da típica da espécie. Preferimos considerar por enquanto, a exemplo de Sant'Anna (1984), as duas variedades separadamente, embora pontuação da parede seja uma característica que aparece melhor visível com a idade do indivíduo e, melhor ainda, com a impregnação da parede por sais do ambiente, principalmente, sais de ferro.

Skuja (1956) propôs a reunião da f. apiculatum Reinsch e da var. scrobiculatum Lagerheim numa única variedade, que denominou var. apiculatoscrobiculatum (Reinsch, Lagerheim) Skuja. Trata-se de uma proposição inusitada desde que Skuja (1956) uniu os epítetos da variedade e da forma taxonômica num só, hifenizando o epíteto resultante e atribuindo a autoridade de seu epíteto misto aos dois autores: Reinsch e Lagerheim. Tal situação não está de acordo com o Código Internacional de Nomenclatura Botânica (edição do Congresso de Viena), pois Skuja (1956) deveria ter optado pelo mais antigo dos dois epítetos das plantas que reuniu e, então, efetuar a nova combinação. Polyedrium minimum A. Braun $\mathrm{f}$. apiculata Reinsch e Tetraëdron minimum (A. Braun) Hansgirg var. scrobiculatum Lagerheim datam do mesmo ano: 1888 , sendo o primeiro de julho e o segundo de outubro. Assim, o epíteto apiculata tem precedência sobre scrobiculatum.

O nome T. minimum (A. Braun) Hansgirg var. apiculato-scrobiculatum (Reinsch, Lagerheim) Skuja ou T. minimum (A. Braun) Hansgirg var. apiculatoscrobiculatum (Reinsch) Skuja, como referido no "Algaebase", é provisório e sujeito a verificação conforme o próprio "Algaebase" (www.algaebase.org).

* Tetraëdron planctonicum G.M. Smith, Bulletin of the Torrey Botanical Club 43: 479, fig. 19-20. 1916.

Figura 38
Células isoladas, achatadas, 4-5-angulares, margem entre ângulos convexa, ângulos prolongados em processo curto, extremidade 2-denticulada, 30,5-34 $\mu \mathrm{m}$ de um ângulo ao outro oposto incluindo espinhos, 18,4-18,8 um sem espinhos, espinhos amplamente divergentes entre si, às vezes 2 -furcado, com dentículos curtos, levemente divergentes entre si; cloroplastídio 1, parietal; pirenóide não observado.

Hábitat: plâncton no lago artificial situado próximo da portaria $\mathrm{n}^{0} 2$ do Instituto de Botânica (Leite 1974).

Tetraëdron planctonicum G.M. Smith lembra $T$. limneticum Borge, do qual difere por possuir a margem convexa e não côncava entre os ângulos celulares.

* Tetraëdron quadrilobatum G.M. Smith, Transactions of the Wisconsin Academy of Sciences, Arts and Letters 20: 333, pl. 8, fig. 14-18. 1922.

Figura 39

Células isoladas, achatadas ou tetraédricas, margem entre ângulos mais ou menos côncava, ângulos levemente acuminados a amplamente arredondados, destituídos de espinho ou processo, 10$13 \mu \mathrm{m}$ de um ângulo ao outro oposto; cloroplastídio 1 , parietal; pirenóide 1, central, às vezes ausente.

Hábitat: plâncton no Lago das Garças (SP390899); Sant'Anna et al. (1989).

* Tetraëdron regulare Kützing var. regulare, Phycologia germanica: 129. 1845.

Figuras 40-41

Células isoladas, achatadas, tetraédricas, ângulos acuminados, terminados em 1 espinho bastante curto, 22,5-25 $\mu \mathrm{m}$ de um ângulo ao outro oposto incluindo espinhos, 16-17 $\mu \mathrm{m}$ sem espinhos; cloroplastídio 1, parietal; pirenóide ausente.

Hábitat: plâncton no lago artificial situado próximo da portaria $\mathrm{n}^{\mathrm{o}} 2$ do Instituto de Botânica (Leite 1974) e no Lago das Garças (Tucci et al. 2006).

Tetraëdron regulare Kützing é prontamente reconhecido, dentre as espécies do gênero, pela forma tetraédrica da célula. Por outro lado, quanto à mesma forma, T. regulare Kützing pode ser facilmente confundido com representantes de Tetraplektron, especialmente de T. laevis (Bourrelly) Ettl, dos quais difere pelo plastídio único em cada célula e não pelos vários, disciformes, sem pirenóide, da última espécie. Desde que a gama de variação das medidas das duas espécies é bastante semelhante, exemplares 
sem plastídio são de identificação bastante difícil, senão impossível.

Tucci et al. (2006) identificaram espécimes desta espécie coletados no Lago das Garças, que mediram 6,5-7,5 um de diâmetro.

* Tetraëdron triangulare Koršikov, Protococcineae: 239, fig. 180. 1953.

Figura 42

Células isoladas, achatadas, 3-angulares, margem entre ângulos reta ou pouco côncava na parte média, ângulos arredondados, terminados em 1 espinho reto, curto, 8,5-10,5 $\mu \mathrm{m}$ de um ângulo ao outro oposto; cloroplastídio 1, parietal; pirenóide 1, central.

Hábitat: plâncton no Lago das Garças (Tucci et al. 2006).

* Tetraëdron trigonum (Nägeli) Hansgirg f.trigonum, Hedwigia 27(5-6): 130. 1888 三Polyedrium trigonum Nägeli, Gattungen einzelliger Algen: 84, pl. 4, fig. B, 1a-b. 1849.

Figura 43

Células isoladas, achatadas, 3-angulares, margem entre os ângulos em geral reta, suavemente convexa ou retusa na parte média, ângulos mais ou menos acuminados, terminados em 1 espinho curto, reto ou curvo, ca. $20 \mu \mathrm{m}$ de um ângulo ao outro oposto incluindo espinhos; cloroplastídio 1, parietal; pirenóide 1, central.

Hábitat: plâncton no lago artificial situado próximo da portaria $\mathrm{n}^{\circ} 2$ do Instituto de Botânica (Leite 1974).

* Tetraëdron trigonum (Nägeli) Hansgirg f. gracile (Reinsch) De Toni, Sylloge algarum 2: 598. 1889 Polyedrium trigonum Nägeli f. gracile Reinsch, Die Algenflora des mittleren Theiles von Franken: 75, pl. 3, fig. 1a-b. 1867.

Figura 44

Difere da variedade-tipo da espécie por possuir a margem entre os ângulos côncava e as projeções angulares mais estreitas e pronunciadas; célula 25-32 $\mu \mathrm{m}$ de um ângulo ao outro oposto incluindo espinhos.

Hábitat: plâncton no lago artificial situado próximo da portaria $\mathrm{n}^{\circ} 2$ do Instituto de Botânica (Leite 1974).

Autores como Smith (1920) e Prescott (1962) consideraram a presente forma ao nível de variedade da mesma espécie, a var. gracile (Reinsch) De Toni.

\section{COCCOMYXACEAE}

Indivíduos unicelulares imóveis, solitários que jamais formam colônia sem forma definida envolta por mucilagem copiosa. As células podem ser ovóides, globosas, elipsoidais, fusiformes, sigmóides ou aproximadamente cilíndricas. O cloroplastídio pode ser único ou ocorrerem vários, sempre laminares e de posição parietal e que pode ou não possuir um pirenóide. Inexistem vacúolos pulsáteis. O único processo de reprodução dos membros desta família é por autosporulação, jamais por divisão celular ou zoósporos (Bourrelly 1966).

\section{Elakatothrix Wille}

Indivíduos coloniais, cujas colônias são formadas por duas, quatro ou muitas células fusiformes, retas ou encurvadas, nas quais um dos pólos ou ambos afilam gradualmente até a extremidade acuminada. A matriz colonial de mucilagem é bastante ampla e uniforme. As células estão dispostas no interior da mucilagem com seus eixos maiores mais ou menos paralelos entre si. O cloroplastídio é único por célula, laminar, ocupa posição parietal e possui um ou dois pirenóides. Em alguns raros casos, ocorrem dois pirenóides por célula de posição mais ou menos central no plastídio.

Uma única espécie foi identificada.

Elakatothrix gelatinosa Wille, Biologisches Zentralblatt 18: 302, fig. 59A-C, 62. 1898.

Figura 46

Colônias com 2, 4 ou 8 células; células aproximadamente fusiformes, um dos pólos acuminado, o outro arredondado-truncado, 9-13 $\mu \mathrm{m}$ compr., 4-5,5 $\mu \mathrm{m}$ larg.; plastídio laminar, parietal; pirenóide 1, aproximadamente central na célula.

Hábitat: plâncton e perifíton no Lago do IAG (Ferragut et al. 2005).

\section{Keratococcus Pascher}

Indivíduos unicelulares, solitários e de vida livre. Quando aderidos a um substrato, podem formar grupos de duas a quatro células. A célula é fusiforme, reta, muito suavemente curva ou torcida na forma de um "S", com os pólos afilados e pontiagudos ou arredondados, às vezes terminando em um espinho sólido e pontiagudo. A parede celular é delgada, lisa e incolor. O único cloroplastídio é laminar, tem situação parietal e lateral e ocupa não mais do que a metade da célula. Um pirenóide é quase sempre presente, raro ausente, embora sua visualização não seja fácil. 

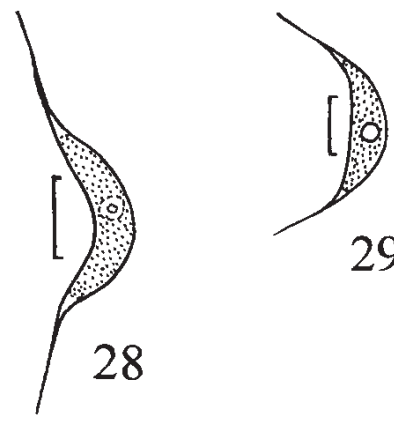

29
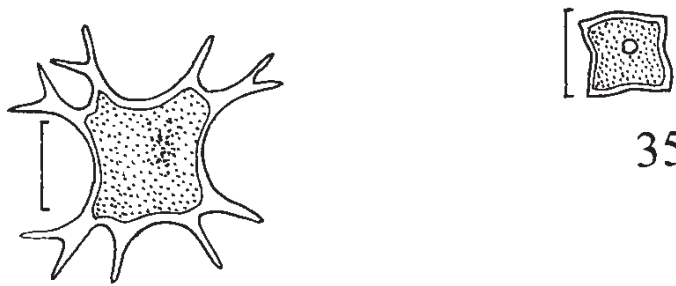

35

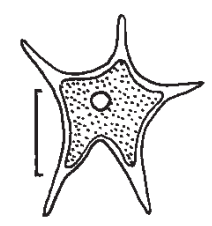

32

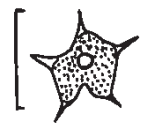

33

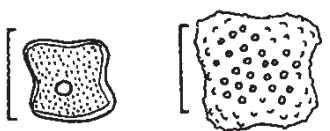

36

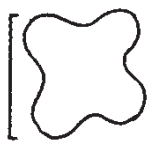

39
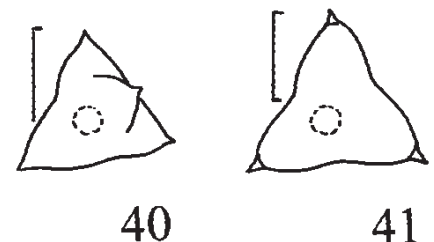

40

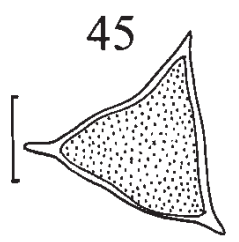

42

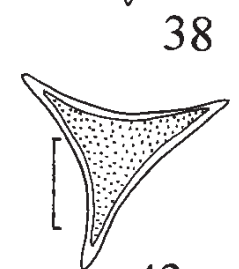

43

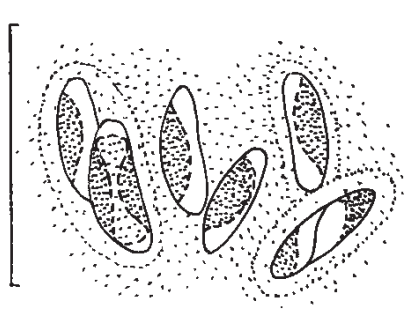

44

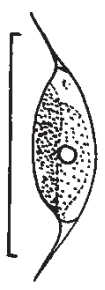

47

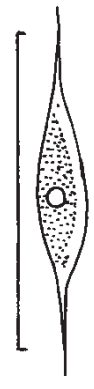

48

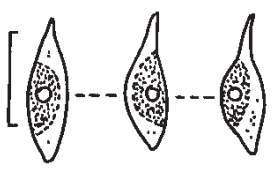

46

Figuras 28-48. Espécies de Chlorococcaceae do Parque Estadual das Fontes do Ipiranga. 28. Schroederia antillarum (de Bicudo \& Bicudo 1970). 29. Schroederia indica. 30-31. Schroderia spiralis. 32-33. Tetraëdron caudatum (32 de Sant'Anna 1984). 34. Tetraëdron gracile (de Sant'Anna 1984). 35-36. Tetraëdron minimum var. minimum (de Sant'Anna 1984). 37. Tetraëdron minimum var. scrobiculatum (de Sant'Anna 1984). 38. Tetraëdron planctonicum (de Sant'Anna 1984). 39. Tetraëdron quadrilobatum. 40-41. Tetraëdron regulare. 42. Tetraëdron triangulare (de Sant'Anna 1984). 43. Tetraëdron trigonum f.trigonum (de Sant'Anna 1984). 44. Tetraëdron trigonum f. gracile . 45. Coccomyxa lacustris. 46. Elakatothrix gelatinosa. 47. Keratococcus bicaudatus. 48. Keratococcus mucicola.

Figures 28-48. Species of Chlorococcaceae of the "Parque Estadual das Fontes do Ipiranga". 28. Schroederia antillarum (from Bicudo \& Bicudo 1970). 29. Schroederia indica.30-31. Schroderia spiralis. 32-33. Tetraëdron caudatum (32 from Sant'Anna 1984). 34. Tetraëdron gracile (from Sant'Anna 1984). 35-36. Tetraëdron minimum var. minimum (from Sant'Anna 1984). 37. Tetraëdron minimum var. scrobiculatum (from Sant'Anna 1984). Figure 38. Tetraëdron planctonicum (from Sant'Anna 1984). 39. Tetraëdron quadrilobatum. $40-41$. Tetraëdron regulare. 42. Tetraëdron triangulare (from Sant'Anna 1984). 43. Tetraëdron trigonum f. trigonum (from Sant'Anna 1984). Figure 44. Tetraëdron trigonum f. gracile. Figure 45. Coccomyxa lacustris. 46. Elakatothrix gelatinosa. 47. Keratococcus bicaudatus. 48. Keratococcus mucicola. 
Chave para as espécies de Keratococcus

1. Indivíduos formando grupos de 2-4 K. mucicola

1. Indivíduos isolados, não formando grupos.

2. Cloroplastídio ocupando ca. $3 / 4$ da periferia celular. K. bicaudatus

2. Cloroplastídio ocupando quase toda a periferia celular. K. suecicus

Keratococcus bicaudatus (A. Braun) Boye-Petersen, Botany of Iceland 2: 429. 1928. Dactylococcus caudatus A. Braun in Rabenhorst, Flora europaeae algarum aquae dulcis et submarinae 3: 10, fig. b-3 . 1868 (em parte).

Figura 47

Indivíduos isolados; célula fusiforme ou sigmóide, 13,5-16 $\mu \mathrm{m}$ compr., 3,6-4,4 $\mu \mathrm{m}$ larg.; parede celular delicada, firme; cloroplastídio 1, parietal, laminar, ocupando ca. $3 / 4$ da periferia celular, bordo liso; pirenóide 1.

Hábitat: plâncton no lago artificial situado próximo da portaria $\mathrm{n}^{\mathrm{o}} 2$ do Instituto de Botânica [Leite 1974: como Ourococcus bicaudatus (A. Braun) Grobéty] e no Lago das Garças (SP390902), Sant'Anna et al. (1989) e Tucci et al. (2006).

Sant'Anna et al. (1989) documentaram a ocorrência, no Lago das Garças, de espécimes bastante maiores (30-32 $\mu \mathrm{m}$ compr., 6-7 $\mu \mathrm{m}$ larg.) dos que os atualmente identificados de material do mesmo ambiente. Todavia, uns e outros exemplares encaixam-se, plenamente, na faixa de variação métrica da espécie.

Keratococcus mucicola (Hustedt) Hindák, Biologické

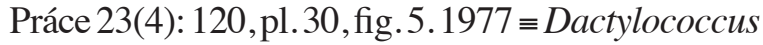
mucicola Hustedt, Hedwigia 48: 141, fig. 1. 1909.

Figura 48

Indivíduos formando grupos de 2 ou 4 células; células assimétricas, irregularmente fusiformes, 9,511,5 $\mu \mathrm{m}$ compr., 2-3 $\mu \mathrm{m}$ larg.; parede celular delicada, firme; cloroplastídio 1, parietal, laminar, ocupando ca. 1/2 da periferia celular, bordo liso, raro levemente lobado; pirenóide 1.

Hábitat: perifíton no Lago das Garças (SP390902).

Não foram encontrados exemplares isolados de K. mucicola (Hustedt) Hindák. Todos os espécimes coletados apareceram sobre algum tipo de substrato formando pequenos grupos de duas ou quatro células.
Keratococcus suecicus Hindák, Biologické Práce 23(4): 119, pl. 30, fig. 3-4, pl. 51, fig. 1. 1977.

Indivíduos isolados; células aproximadamente lunadas a fusiformes, fortemente curvadas, 12-75 $\mu \mathrm{m}$ compr., (2,5-)5-8 $\mu \mathrm{m}$ larg., espinhos 4-20 $\mu \mathrm{m}$ compr.; parede celular delicada, firme; cloroplastídio 1, parietal, laminar, ocupando quase toda a periferia celular, bordo liso; pirenóide 1 .

Hábitat: perifíton no Lago das Garças (SP390902) e Sant'Anna et al. (1989).

Planktococcomyxa Kostikov, Darienko, Lukešová \& Hoffmann

Indivíduos unicelulares, solitários, de vida livre, que raramente formam colônias com quatro células. Seja isolada seja constituindo colônia as células são sempre envoltas por copiosa mucilagem. A célula é elíptica, com pólos arredondados. O cloroplastídio é único, laminar, tem situação parietal e lateral e reveste pouco mais do que a metade do protoplasma, sempre deslocado para um dos lados. Pirenóide ausente. A parede celular é delgada e lisa.

Kostikov et al. (2002) efetuaram uma revisão das Radiococcaceae (exceto a subfamília Dictyochlorelloideae) com base nas seguintes características tradicionais de fácil visualização: (1) capacidade de formar células esféricas, (2) presença ou ausência de pirenóide, (3) número de autósporos produzidos (só dois, em geral dois, só quatro ou oito ou em geral quatro ou oito) e (4) comportamento da parede da célula esporangial durante a libertação dos autósporos (por ruptura ou gelatinização). Além dessas características, que chamou de principais, também usou as seguintes outras, que denominou secundárias: (1) capacidade de formar colônias tubulares ramificadas, (2) número de cloroplastídios por célula e (3) capacidade de formar colônias laminares sarcinóides. O uso consistente dessas características permitiu aos referidos autores separar 25 gêneros, 10 dos quais (inclusive Planktococcomyxa) foram descritos como novos para a Ciência. Kostikov et al. (2002) afirmaram que o sistema que idealizaram é artificial, porém, permite identificar de maneira pronta os gêneros e as espécies incluídos na família Radiococcaceae, bem como encaixar de modo fácil os novos gêneros que venham a ser descritos e nela incluídos.

Uma única espécie foi identificada. 
Planktococcomyxa lacustris (Chodat) Kostikov, Darienko, Lukešová \& Hoffmann, Algological Studies 104: 50. 2002 三Dactylococcus lacustris Chodat, Bulletin de 1'Herbier Boissier 5(5): 120, pl. 11, fig. 7-8. 1897.

Figura 45

Células elípticas, simétricas, pólos arredondados, envoltas por copiosa bainha de mucilagem, 4-5 $\mu \mathrm{m}$ compr., 2,5-3 $\mu \mathrm{m}$ larg.; cloroplastídio parietal, laminar, deslocado para um dos lados; pirenóide ausente; colônias com 4 células, 13,8-28 $\mu$ m compr., 9,9-17,2 $\mu \mathrm{m}$ larg.

Hábitat: perifíton no Lago das Ninféias (SP255743) e em um córrego sem nome (amostra não-preservada).
As colônias coletadas de C. lacustris (Chodat) Pascher foram sempre formadas por quatro células embebidas em copiosa mucilagem, porém, jamais macroscópicas.

Segundo Komárek \& Fott (1983), C. lacustris (Chodat) Pascher difere de $C$. confluens (Kützing) Fott pelo tipo de ambiente que habitam, pois a primeira é planctônica e a segunda, aerófita. Além disso, há diferença na forma das células, pois são elípticas e sempre simétricas em $C$. lacustris (Chodat) Pascher e elípticas, porém, comumente assimétricas em $C$. confluens (Kützing) Fott. Esta diferença é bastante fácil de ser detectada ao microscópio.

Material excluído: Elakatothrix gelatinosa Wille (Lopes 1999, Vercellino 2001; Lago do IAG): falta de ilustração e medidas.

Chave para identificação dos gêneros, espécies, variedades e formas taxonômicas das famílias Chlorococcaceae e Coccomyxaceae do PEFI

1 Célula epífita.

2. Célula sem estrutura de fixação (Apodochloris) A. polymorpha

2. Célula com estrutura de fixação (Characium)

3 Célula bilateralmente simétrica.

4. Ápice celular mucronado * C. acuminatum

4. Ápice celular agudo C. rostratum

3. Célula bilateralmente assimétrica.

5. Ápice celular prolongado em espinho relativamente longo C. transvaalense

5. Ápice celular não prolongado em espinho.

6. Pedículo longo, 1/3-1/2 do comprimento total da célula

C. ornithocephalum var. ornithocephalum

6. Pedículo curto, ca. 1/10 do comprimento total da célula.

7. Célula fusiforme ou subfusiforme.

8. Célula 15-18,8 $\mu \mathrm{m}$ compr., 4-5 $\mu \mathrm{m}$ larg. * C. ornithocephalum var. pringsheimii

8. Célula 29-32 $\mu \mathrm{m}$ compr., 6-6,5 $\mu \mathrm{m}$ larg. C. ensiforme

7. Célula lanceolada ou subclavada.

9. Célula moderadamente lanceolada, ápice acuminado

* C. ornithocephalum var. adolescens

9. Célula subclavada, ápice arredondado C. strictum

1. Célula de vida livre, isolada ou formando colônia.

10. Célula formando colônia envolvida por mucilagem.

11. Célula com um pólo acuminado e o outro arredondado-truncado (Elakatothix) E. gelatinosa

11. Célula com ambos os pólos arredondados .(Planktococcomyxa) P. lacustris

10. Célula isolada, não formando colônia.

12. Célula bilateralmente assimétrica (Schroederia)

13. Setas longas, retas ou muito levemente curvas S. antillarum

13. Setas relativamente curtas, retas ou regular ou irregularmente curvas, até torcidas em espiral.

14. Setas relativamente curtas, regular ou irregularmente curvas, até torcidas em espiral 
14. Setas relativamente curtas, retas, raro muito pouco curvas S. indica

12. Célula bilateralmente simétrica.

15. Célula 3-5-angulares.

16. Ângulos com 2-4 espinhos cada.

(Polyedriopsis) * P. spinulosa

16. Ângulos lisos, sem espinhos

.(Tetraëdron)

17. Cloroplastídio com pirenóide.

18. Célula 3-angular.

19. Célula $8,5-10,5 \mu \mathrm{m}$ de um ângulo ao outro

* T. triangulare

19. Célula ca $20 \mu \mathrm{m}$ de um ângulo ao outro.

20. Ângulos pouco pronunciados que alcançam no máximo $1 / 4$ do corpo celular

* T. trigonum var. trigonum

20. Ângulos bastante pronunciados que alcançam no mínimo $1 / 3$ do corpo celular * T. trigonum f. gracile

18. Célula 4-5-angular.

21. Célula 4-angular.

22. Ângulos arredondados ou acuminados, destituídos de espinho ou processo.

23. Ângulos acuminado

23. Ângulos amplamente arredondados.

24. Ângulos acutangular-arredondados.....* T. quadrilobulatum (em parte)

24. Ângulos retangular-arredondados.

25. Parede celular lisa

* T. minimum var. minimum

25. Parede celular pontuada.

* T. minimum var. scrobiculatum

22. Ângulos com espinho ou extremidade 2-denticulada ou 2-lobulada.

26. Ângulos prolongados em processo curto, extremidade

2-denticulada.

* T. planctonicum (em parte)

26. Ângulos 2-lobados, lobos relativamente longos, extremidade

2-denticulada.

* T. gracile

21. Célula 5-angular.

27. Célula com 4 lados retos a suavemente côncavos e o outro com uma incisão profunda.

T. caudatum

27. Célula com os 5 lados convexos * T. planctonicum (em parte)

17. Cloroplastídio sem pirenóide.

28. Ângulos acuminados, terminados em espinho bastante curto

* T. regulare

28. Ângulos destituídos de espinho ou processo

15. Célula esférica, elipsóide, oblonga, lunada ou fusiforme.

29. Célula lunada ou fusiforme.

30. Célula com 1 pólo pontiagudo e o outro 2 -furcado

* T. quadrilobulatum (em parte)

30. Célula com ambos os pólos afilados e pontiagudos ou arredondados, às vezes terminando em um espinho sólido e pontiagudo

(Keratococcus)

31. Indivíduos formando grupos de 2-4

K. mucicola

31. Indivíduos isolados, não formando grupos.

32. Cloroplastídio ocupando ca. 3/4 da periferia celular

K. bicaudatus

32. Cloroplastídio ocupando quase toda a periferia celular.

K. suecicus

29. Célula esférica, elipsóide ou oblonga.

33. Cloroplastídios vários por célula .

33. Cloroplastídio único por célula

.(Planktosphaeria) $*$ P. gelatinosa

34. Célula oblonga

(Chlorococcum)

34. Célula esférica a elipsóide. C. acidum

35. Célula elipsóide C. ellipsoideum

35. Célula esférica ou quase.

36. Célula 5-10 $\mu \mathrm{m}$ diâm.

C. infusionum

36. Célula ca. $16,3 \mu \mathrm{m}$ diâm.

C. minimum 
As duas famílias foram bem representadas na área do PEFI, ocorrendo em 10 ambientes distintos, que incluíram reservatórios e um riacho sem nome cuja localização não foi fornecida no rótulo original de coleta. Ocorreram, entretanto, dominantemente em ambientes do tipo semilêntico (reservatórios), pois apenas Chlorococcum acidum Archibald \& Bold foi coletado de um ambiente lótico (riacho sem nome).

$\mathrm{O}$ ambiente taxonomicamente mais rico foi o Lago das Garças, de onde foram coletados 17 táxons. Vieram, em seguida, o Lago das Ninféias com 12, o lago situado próximo da Portaria $\mathrm{n}^{\mathrm{o}} 2$ do Jardim Botânico de São Paulo com seis e o Lago do IAG com cinco. Contudo, o lago próximo da Portaria ${ }^{\circ}$ 2 é abastecido, através de uma comporta, com água do Lago das Garças. Exceto este último ambiente, os demais três têm sido, coincidentemente, os mais e melhor estudados. Consequentemente, o maior número de táxons encontrados nesses três ambientes em relação aos demais do PEFI pode ser o simples resultado do maior esforço amostral neles realizado e, mais do que tudo, no Lago das Garças.

Quatorze táxons foram coletados apenas do plâncton e outros 14 apenas do perifíton. Cinco táxons [Apodochloris polymorpha (Bischoff \& Bold) Komárek, Elakatothrix gelatinosa Wille, Schroederia antillarum Komárek, Tetraëdron caudatum (Corda) Hansgirg e T. minimum (A. Braun) Hansgirg var. "apiculato-scrobiculatum" (Reinsch, Lagerheim) Skuja] foram coletados simultaneamente em um e outro tipo de ambiente. Este fato mostra a enorme importância dos levantamentos florísticos incluírem amostragem nos dois tipos de ambiente, plâncton e perifíton, pois $42,4 \%$ dos táxons ora identificados ocorreram exclusivamente no plâncton, outros $42,4 \%$ só no perifíton e $15,2 \%$ tanto em um quanto em outro ambiente, o que quer dizer que, em última instância, a não-coleta de material perifítico incorreria na perda de $42,4 \%$ da riqueza taxonômica ora identificada.

A despeito do grande esforço de busca, dos 34 táxons atualmente identificados e que incluíram 30 espécies e três variedades e uma forma taxonômica não-típicas de suas respectivas espécies e variedade, 16 (ou equivalente a $47 \%$ do total dos táxons identificados) não foram reencontrados nas preparações feitas de material dos ambientes para os quais foram inventariados nem nas amostras preservadas depositadas no Herbário Científico do Estado "Maria Eneyda P. Kauffmann Fidalgo". Estas amostras foram coletadas no período de março de 1972 a dezembro de 1977, fixadas e preservadas em solução de Transeau e serviram de base para realização do trabalho de Sant'Anna (1984). Tal fato gerou grande preocupação nos atuais autores com o grau de preservação das amostras, isto é, com o fato do tipo de solução fixadora e preservadora utilizada pelos especialistas da instituição não estar possibilitando a preservação dos materiais, desde que um serviço criterioso de manutenção dessas coleções tem sido rigorosamente feito pela Curadoria competente.

\section{Agradecimentos}

Os autores expressam seu melhor agradecimento à Secretaria de Educação do Estado de São Paulo por bolsa de doutorado outorgada a Sidney Fernandes e ao CNPq, Conselho Nacional de Desenvolvimento Científico e Tecnológico, por bolsa de produtividade outorgada a Carlos Eduardo de Mattos Bicudo (processo no 303876/2004-2).

\section{Literatura citada}

AlgaBase. http:// www.algaebase.org. (acesso em 30 de setembro de 2008).

Bicudo, C.E.M. \& Bicudo, R.M.T. 1967. Floating communities of algae in an artificial pond in the Parque do Estado, São Paulo, Brazil. Journal of Phycology 3: 233-234.

Bicudo, C.E.M. \& Bicudo, R.M.T. 1970. Algas de águas continentais brasileiras: chave ilustrada para identificação de gêneros. Fundação Brasileira para o Desenvolvimento do Ensino de Ciências, São Paulo.

Bicudo, C.E.M. \& Menezes, M. 2006. Gêneros de algas de águas continentais do Brasil: chave para identificação e descrições. 2 ed. RiMa Editora, São Carlos.

Bicudo, D.C. 1996. Algas epífitas do Lago das Ninféias, São Paulo, Brasil, 4: Chlorophyceae, Oedogoniophyceae e Zygnemaphyceae. Revista Brasileira de Biologia 56: 345-374.

Bourrelly, P. 1966. Les algues d'eau douce: initiation à la systématique, 1: Chlorophycées, v. 1, Éditions N. Boubée, Paris.

Braun, A. 1855. Algarum unicellularium genera nova et minus cognitis. W. Engelmann, Leipzig.

Cholnoky, B.J. 1954. Ein Beitrag zur Kenntnis der Algenflora des Mogolflusses in Nordost-Transvaal. Österreichische botanische Zeitschrift 101: 118-139.

Ettl, H. 1968. Ein Beitrag zur Kenntnis der Algenflora Tirols. Bericht des Naturwissenschaftlich-medizinischen Vereins in Innsbruck 56: 177-354.

Ferragut, C., Lopes, M.R.M., Bicudo, D.C., Bicudo, C.E.M. \& Vercellino, I.S. 2005. Ficoflórula perifítica e planctônica (exceto Bacillariophyceae) de um 
reservatório oligotrófico raso (Lago do IAG, São Paulo). Hoehnea 32: 137-184.

Komárek,J. \& Fott, B. 1983. Chlorophyceae (Grünalgen), Ordnung Chlorococcales. In: G. Huber-Pestalozzi (eds.). Das Phytoplankton des Süsswassers. Ed. Schweizerbart'sche Verlagsbuchhandlung (Nägele und Obermiller), Stuttgart.v.7(1).

Kostikov, I., Darienko, T., Lukešová, A. \& Hoffmann, L. 2002. Revision of the classification system of Radiococcaceae Fott \& Komárek (except the subfamily Dictyochlorelloideae) (Chlorophyta). Algological Studies 104: 23-58.

Leite, C.R. 1974. Contribuição ao conhecimento das Chlorococcales (Chlorophyceae) planctonicas do Parque Estadual das Fontes do Ipiranga, São Paulo, Brasil. Dissertação de Mestrado, Universidade de São Paulo, São Paulo.

Lopes, M.R.M. 1999. Eventos perturbatórios que afetam a biomassa, a composição e a diversidade de espécies do fitoplâncton em um lago tropical oligotrófico raso (Lago do Instituto Astronômico e Geofísico, São Paulo, SP). Tese de Doutorado, Universidade de São Paulo, São Paulo.

Moseley, H.N. 1875. Notes on fresh-water algae obtained at the Boiling Springs at Furnas, St. Michael's, Azores, and their neighborhood. Linnean Journal of Botany, new series 14: 321-325.

Nogueira, I.S. 1991. Primeiro registro de ocorrência de Scottiellopsis terrestris (Chlorellales, Chlorellaceae) em ambiente fitotélmico tropical. Revista Brasileira de Biologia 59: 437-444.

Prescott, G.W. 1962. Algae of the Western Great Lakes area with an illustrated key of the genera of desmids and freshwater diatoms. Wm C. Brown Company Publishers, Dubuque.

Sant'Anna, C.L. 1984. Chlorococcales (Chlorophyceae) do Estado de São Paulo, Brasil. Bibliotheca Phycologica 67: 1-348.

Sant'Anna, C.L., Azevedo, M.T.P. \& Sormus, L. 1989. Fitoplâncton do Lago das Garças, Parque Estadual das Fontes do Ipiranga. São Paulo, SP, Brasil: estudo taxonômico e aspectos ecológicos. Hoehnea 16: 89-131.

Skuja, H. 1956. Taxonomische und biologische Studien über das Phytoplankton Schwedischer Binnengewasser. Nova Acta Regiae Societatis Scientiarum Upsaliensis, série 4, 16: 1-404.

Smith, G.M. 1920. Phytoplankton of the inland lakes of Wisconsin, 1: Myxophyceae, Phaeophyceae, Heterokonteae, and Chlorophyceae exclusive of the Desmidiaceae. Bulletin of the Wisconsin Geological and Natural History Survey 57: 1-243.

Sophia, M.G., Carmo, B.P. \& Huszar, M.L.M. 2004. Desmids of phytotelm terrestrial Bromeliads from the National Park "Restinga de Jurubatiba", southeast Brazil. Algological Studies 114: 99-119.

Tucci, A., Sant'Anna, C.L., Gentil, R.G. \& Azevedo, M.T.P. 2006. Fitoplâncton do Lago das Garças, São Paulo, Brasil: um reservatório urbano eutrófico. Hoehnea 33: 147-175.

Vercellino, I.S. 2001. Sucessão da comunidade de algas perifíticas em dois reservatórios do Parque Estadual das Fontes do Ipiranga, São Paulo: influência do estado trófico e período climatológico. Dissertação de Mestrado, Universidade Estadual Paulista, Rio Claro. 